\title{
CELLULOSOLITIC MICROORGANISMS ACTIVITY AS AN INDICATOR OF DETAILS FUNERAL CEREMONY ${ }^{1}$
}

\author{
Liudmila N. Plekhanova \\ Institute of Physico-Chemical and Biological Problems of Soil Science of the Russian Academy of Sciences, \\ Pushchino, Russian Federation \\ Natalya N. Kashirskaya \\ Institute of Physico-Chemical and Biological Problems of Soil Science of the Russian Academy of Sciences, \\ Pushchino, Russian Federation
}

\author{
Alexander S. Syrovatko \\ Kolomna Archeological Research Center, Kolomna, Russian Federation
}

\begin{abstract}
The article describes the results and the methodology for determining the initial presence of wares containing cellulose in the Vyatichi funeral ceremony in the Middle Ages in the natural zone of the southern taiga, Moscow region. Cellulose is a high molecular weight polymer. Cellulose (in other words - fiber) contains up to half of all the organic carbon of the biosphere, therefore, the prevalence of various microorganisms utilizing cellulose is quite high. In addition, the prevalence of this trophic group of microorganisms significantly complicates the diagnosis in archaeological contexts, since it's necessary to understand the total number of these microorganisms on different depths in certain soil types and certain climatic zones. To overcome this difficulty, we conducted a two-month experiment to determine the rates of decomposition of the added cellulose substrate by soils from the adjacent structures of cremated burials using method, providing results comparable with published data. For the first time, there was made an attempt to identify soils of cremated burials with an increased content of cellulose, by analogy to microbiological methods of identifying keratin-containing substrates of ancient burials. The presence of cellulolytic microorganisms was identified by counting of colony forming units after planting on a solid nutrient environment soil agar enriched in carboxymethyl cellulose. The object of the experiments was soil samples from medieval burials with cremations. Comparisons were made with the background soil of the same age as cremations (XII century), which I have been developing according to the zonal type on the kurgan mound nearby to cremated burials. Three sites with i maxima activity were revealed, according to the archaeological context. The article continues the cycle of experimental planting of trophic groups of microorganisms for the purpose of indicating substances that entered the soil at different periods of time, from antiquity to the Middle Ages, and have been utilized by microorganisms up to nowadays.

Key words: paleosol, cellulose, cellulase, microorganisms, funeral soil, cremation, burial.
\end{abstract}

Citation. Plekhanova L.N., Kashirskaya N.N., Syrovatko A.S., 2020. Cellulosolitic Microorganisms Activity as an Indicator of Details Funeral Ceremony. The Lower Volga Archaeological Bulletin, vol. 19, no. 1, pp. 116-129. (in Russian). DOI: https://doi.org/10.15688/nav.jvolsu.2020.1.6

УДК 930.26(470+571):903.5

Дата поступления статьи: 12.03.2020

ББК $63.48(2)-7$

Дата принятия статьи: 29.04.2020

\section{АКТИВНОСТЬ ЦЕЛЛЮЛОЗОЛИТИЧЕСКИХ МИКРООРГАНИЗМОВ В ГРУНТАХ КРЕМИРОВАННЫХ ЗАХОРОНЕНИЙ КАК ИНДИКАТОР ДЕТАЛЕЙ ПОГРЕБАЛЬНОГО ОБРЯДА ${ }^{1}$}

\author{
Людмила Николаевна Плеханова \\ Институг физико-химических и биологических проблем почвоведения РАН, \\ г. Пущино, Российская Федерация
}


Активность целлюлозолитических микроорганизмов в грунтах кремированных захоронений

\section{Наталья Николаевна Каширская}

Институт физико-химических и биологических проблем почвоведения РАН, г. Пущино, Российская Федерация

\section{Александр Сергеевич Сыроватко}

Коломенский научный археологический центр, г. Коломна, Российская Федерация

Аннотация. В статье описаны результаты и методика определения исходного присутствия изделий, содержащих целлюлозу, в погребальном обряде вятичей в эпоху Средневековья в природной зоне южной тайги, на административной территории Московской области. Целлюлоза, или клетчатка - это высокомолекулярный полимер с неразветвленной цепью. В ее состав входит до половины всего органического углерода биосферы, поэтому весьма высока распространенность различных микроорганизмов, утилизирующих целлюлозу. Такая ситуация значительно затрудняет диагностику в археологических контекстах, поскольку необходимо понимание общего количества этих микроорганизмов по глубинам на конкретном типе почв и в конкретной природной зоне. Для выхода из такого положения нами проведен двухмесячный эксперимент по определению скоростей разложения внесенного целлюлозного субстрата почвогрунтами из прилегающих конструкций кремированных захоронений методом, дающим сопоставимые результаты с литературными данными. Впервые сделана попытка выявить почвогрунты кремированных захоронений с повышенным содержанием целлюлозы, по аналогии с микробиологическими методами идентификации кератинсодержащих субстратов древних погребений. Наличие целлюлозолитических микроорганизмов определялось подсчетом колониеобразующих единиц после посева на твердую питательную среду - почвенный агар, обогащенный карбоксиметилцеллюлозой. Объектом для экспериментов послужили образцы почвогрунтов из средневековых погребений с кремациями. Сравнения проводили с фоновой почвой одного с кремациями возраста (ХІІ в.), развивающейся по зональному типу на курганной насыпи в непосредственной близости от кремированных захоронений. Выявлено три участка с максимумами активности в соответствии с археологическим контекстом. Работа продолжает цикл экспериментальных посевов трофических групп микроорганизмов с целью индикации веществ, поступавших в почву в различные периоды времени (от древности до Средневековья) и к настоящему времени утилизированных микроорганизмами.

Ключевые слова: палеопочвы, целлюлоза, целлюлаза, микроорганизмы, погребальный грунт, кремации, захоронения.

Цитирование. Плеханова Л. Н., Каширская Н. Н., Сыроватко А. С., 2020. Активность целлюлозолитических микроорганизмов в грунтах кремированных захоронений как индикатор деталей погребального обряда // Нижневолжский археологический вестник. Т. 19, № 1. С. 116-129. DOI: https://doi.org/10.15688/nav.jvolsu.2020.1.6

Различные типы антропогенного воздействия на почву изменяют условия существования почвенных микроорганизмов и нарушают нормальное протекание в почвах процессов микробной трансформации, в том числе оставляя в почвах следы присутствия различных антропогенных нарушений. Последствия антропогенного воздействия на почвенные микроорганизмы (особенно в древности) изучены слабо.

В связи с большим количеством синтезируемой в природе целлюлозы микроорганизмы, разлагающие ее, играют важную роль в процессе минерализации и круговороте углерода. В состав целлюлозы входит более $50 \%$ всего органического углерода биосферы. Целлюлоза является наиболее распространенным полисахаридом растительного мира и представляет собой высокомолеку- лярный полимер с неразветвленной цепью, состоящей из соединенных 1,4-связями глюкозных остатков, число которых в молекуле колеблется от 300 до 3 000. Молекулы целлюлозы соединены в пучки или волокна. Первым этапом в разложении целлюлозы является ферментативный гидролиз этого полимера, процесс протекает под влиянием фермента целлюлазы. Нерастворимая в воде клетчатка превращается в дисахарид целлобиозу, которая затем под влиянием фермента целлобиазы гидролизуется и переходит в глюкозу. При аэробном разложении целлюлозы в основном получаются два продукта углекислый газ и вода. При этом могут накапливаться небольшие количества органических кислот.

Целлюлозоразрушающая активность микроорганизмов, преимущественно бактерий, 
является одним из показателей биологической активности почвы. Последняя играет роль при оценке почвенного плодородия, возможности вовлечения в биологический круговорот содержащихся в почвах элементов азотного и зольного питания. Разнообразие микрофлоры, способной разлагать целлюлозу в почве, позволяет трансформировать это вещество в различных условиях аэрации, при кислой или щелочной $\mathrm{pH}$, низкой или высокой влажности и при разной температуре. Целлюлозу разлагают аэробные микроорганизмы (бактерии, миксобактерии, актиномицеты и грибы) и анаэробные бактерии. Наиболее богато в почве представлена группа аэробных целлюлозоразрушающих микроорганизмов.

В отличие от шерсти, кожи или войлока целлюлоза является основным компонентом тканей, созданных из растительного сырья, например, льна. Нет сомнений в использовании растений для изготовления нитей и тканей в прошлом, разумеется, включая такое близкое к нам время, как Средневековье. Остатки тканей растительного происхождения могут быть надежно идентифицированы с помощью фитолитного анализа, возможно применение споропыльцевого анализа. При этом возможности любого метода имеют ограничения, поэтому в дополнение мы пробуем применить микробиологический метод с целью идентификации поступления целлюлозы антропогенного происхождения в почвогрунты захоронений и погребальных конструкций 800-летнего возраста.

В археологическом почвоведении сделаны значительные успехи не только в определении фосфатного состояния культурных слоев [Каширская и др., 2017б, с. 96] и идентификации различных хозяйственно-бытовых зон древних поселений [Борисов и др., 2013, c. 66-73] (вплоть до пастбищных нагрузок [Плеханова, 2019, с. 53]), но и установлена ценность археологических участков для Красной Книги почв России [Плеханова, 2017, с. 5056]. Данное направление теперь развивается в сторону детализации обрядов и точечного отбора образцов. По аналогии с определением субстратов животного происхождения, кератина и коллагена, входящих в состав шерсти и кожи [Каширская и др., 2018а; Каширская и др., 2018б], сделана попытка применить методы чашечного посева с целью определения поступления целлюлозы.

Любые попадающие в почву вещества (такие как шерсть с кожей или целлюлозосодержащие ткани) будут представлять собой питательные субстраты для почвенных микроорганизмов. Подобный подход к определению животных субстратов ранее применялся для идентификации содержимого ритуальных сосудов [Демкин и др., 2014, с. 148]. Численность молочнокислых бактерий, выращенных из грунта погребального сосуда срубной культуры (XVI-XV вв. до н.э.) увеличилась в три раза на молочной среде по сравнению с контролем, что свидетельствовало о наличии молочного продукта. Поскольку в аэробных условиях клетчатку разлагают многие микроорганизмы различных систематических групп, мы предлагаем при проведении археологических исследований определять увеличение общей численности микробного сообщества на субстрате, содержащем целлюлозу.

По отношению к археологическим субстратам изложим основания, позволяющие нам предполагать отклик целлюлозолитиков на внесение субстратов в древности. Ранее для определения кератинолитической активности в почве был разработан метод приманок [Методы почвенной микробиологии..., 1991], позволяющий судить о степени выраженности данного показателя по интенсивности зарастания субстрата - конского или человеческого волоса - колониями кератинолитических грибов. Для выявления следов навоза, внесенного на поля в древности, использованы микробиологические посевы термофильных микроорганизмов [Чернышева, 2015; Kashirskaya et al., 2019]. Показана высокая сохранность ферментативной активности в культурных слоях поселений эпохи бронзы [Каширская и др., 2017а, с. 1235-1242; Каширская и др., 2020, с. 89]. Иными словами, другие субстраты таким образом определять оказалось возможным.

Что касается целлюлазной активности именно в археологических контекстах, пионерные работы делались в нашей лаборатории на двух объектах. При микробиологических исследованиях каштановых палеопочв, погребенных под валом Анны Иоанновны (17181720 гг.), установлено, что микробные сооб- 
щества погребенных почв отличались от современных по ряду характеристик, в числе которых присутствовала и целлюлазная активность [Чернышева и др., 2013]. Подробнее изучались культурные слои поселения аланской культуры Подкумское-2 (II-IV вв. н.э.) и современных дерново-карбонатных почв вблизи поселения, имеющих различное хозяйственное использование. Наряду с показателями суммарной микробной биомассы, мицелия микроскопических грибов, уреазной активности были выявлены повышенные значения целлюлазной активности именно в культурных слоях. Это позволяет заключить, что исходные характеристики микробиологических свойств профиля более полутора тысяч лет сохраняются с отличиями от фоновых почв [Чернышева, 2015].

Таким образом, целью настоящей работы является попытка оценки численности целлюлозолитических грибов на серых лесных супесчаных почвах для выявления следов привнесения целлюлозы в погребениях и их конструкциях 800-летнего возраста.

\section{Объекты исследования}

Образцы грунта из средневековых погребений отбирались при раскопках курганного могильника Кременье в сезон 2017 года. Могильник расположен в южном Подмосковье, вблизи г. Ступино. Для этого могильника установлен факт сочетания архаичного погребального обряда (грунтовые кремации, помещенные в небольшие ямки или рассыпанные по древней поверхности) с поздней датой - не ранее середины XII в., то есть времени вятичей. Отмечена синхронность грунтовых кремаций курганной части могильника и кладбища, которые представляли собой единый комплекс в глубине «вятичской» территории и с «вятичскими» вещами [Сыроватко, Фомченко, 2015; Сыроватко, 2014]. Образцы для анализа грунтов были взяты из погребений-кремаций $5,8-10$, из участков контакта слоя кремации (темно-серого песка с углем и кальцинированными костями) с материковым светло-серым или светло-желтым песком.

Могильник Щурово расположен также в Московской области, на некотором расстоянии от Кременья, был раскопан в 2010 году.
Образцы отобраны из ямы 47 (участок 15, раскоп II), это кремированное погребение с множественными костями, принявшими вертикальное положение (напоминает иголки ежа), вероятно, после просадки грунта в полость под деревянным перекрытием. Основной образец является «телом» кремации, другой взят из обрамления кремации, представляет собой коричневый грунт. Образец из канавки квадрата 577 (участок 18, раскоп II) отобран для характеристики круговой конструкции, опоясывающей кремированное погребение.

Оба могильника занимают надпойменные террасы, формируясь на песках-супесях, что позволяет проводить сравнения их почв и грунтов.

\section{Методы исследования}

Аппликационные методы разрабатывались при определении биологической активности почвы и рекомендовались для широкого использования [Мишустин, Петрова, 1963; Мишустин, Востров, 1971; Почвенный и биотический мониторинг..., 1996], давая возможность приблизиться к определению протекания процессов в природных условиях луговых биоценозов, оценить микробно-экологические пейзажи по генетическим горизонтам.

В работах по изучению почв в археологических контекстах целлюлазную активность почв определяли аппликационным методом [Методы..., 1991], который был модифицирован в лаборатории археологического почвоведения [Чернышева, 2015]. Для этого в чашки Петри помещали слой почвы, увлажненной до $60 \%$ ПВ, поверх которого помещали стерильную капроновую сетку с ячейками $3 \times 3$ мм. На нее укладывали диск из грубой стерильной льняной ткани, которая также перекрывалась сеткой. Сверху насыпали еще один слой почвы. Чашки помещали в термостат при температуре $30^{\circ} \mathrm{C}$. После 30 суток инкубации образцы ткани извлекали из чашек, тщательно промывали, помещали в сушильный шкаф и высушивали при температуре $105^{\circ} \mathrm{C}$ до постоянного веса. Целлюлазную активность выражали в процентах и рассчитывали по изменению массы образцов ткани после инкубации от исходной. В связи с этим активность выражена в процентах по убыли веса, заложен- 
ного в чашки полотна, что не позволяет сравнивать напрямую эти данные с числом колониеобразующих единиц. Мы использовали этот метод для понимания скоростей разложения целлюлозы в нашем биогеоценозе и сопоставления с литературными данными, увеличив время инкубации с последовательным снятием результатов в пяти повторностях на сроках 10-30-40-60 суток. Основные наши результаты были получены посевами на среды методом, также модифицированном ${ }^{2}$ в нашей лаборатории.

Определение численности колониеобразующих единиц (далее - КОЕ) целлюлозолитических микроорганизмов. Для подсчета общей численности КОЕ на целлюлозном субстрате использовали 20 \% почвенный агар (200 г почвы, 20 г агара на 1 л водопроводной воды) с добавлением 10 \% карбоксиметилцеллюлозы (далее - КМЦ). Стерилизация среды проводилась в 2 этапа при 1 атм (1 дополнительной атмосфере, иными словами, при 2 атмосферах). Для учета контрольной численности КОЕ применяли чистый почвенный агар. Навеску грунта 1 г заливали 10 мл $0,5 \%$ раствора пирофосфата натрия, затем обрабатывали ультразвуком при мощности 50 Вт и частоте 22 кГц в течение 15 с для дезинтеграции почвенных частиц. Из III разведения полученной суспензии на поверхность твердых питательных сред наносили каплю объемом 50 мкл. Инкубация проводилась в течение $10-14$ дней при $26^{\circ} \mathrm{C}$. Общую численность КОЕ после подсчета колоний определяли по формуле:

$$
N=(a / v \times 1000 \times 1000) /\left(m \times \mathrm{K}_{\text {вл }} \times 1000\right),
$$

где $N$ - общая численность КОЕ (тыс. / г почвы), а число колоний на поверхности питательной среды, $v$ - объем капли (мкл), 1000 - число мкл в 1 мл, 1000 третье разведение суспензии; $m$ - масса навески, $\mathrm{K}_{\text {вл }}$ - коэффициент увлажненности почвы для расчета общей численности КОЕ на 1 г абсолютно сухого грунта.

Увеличение общей численности КОЕ на почвенном агаре с карбоксиметилцеллюлозой относительно их общей численности на чистом почвенном агаре определяли по формуле:

$$
X=\left(N_{(П \mathrm{~A}+\text { КМЦ) }}-N_{(П \mathrm{~A})}\right) / N_{(П \mathrm{~A})} \times 100 \%,
$$

где $X$ - искомый прирост общей численности КОЕ микробного сообщества, \%; $N_{\text {(ПА + кмц) }}-$ общая численность КОЕ микроорганизмов на почвенном агаре с карбоксиметилцеллюлозой; $N_{\text {(пА) }}$ - общая численность КОЕ микроорганизмов на чистом почвенном агаре.

Статистическую обработку данных проводили стандартными методами [Дмитриев, 1995].

\section{Результаты и обсуждения}

Одним из показателей скорости биологической трансформации растительных остатков в биоценозе является целлюлазная активность почв. Скорость деструкции целлюлозы в почве может служить индикаторным показателем общей биологической активности в почвах, что, в свою очередь, будет отражать процессы самовосстановления почвенного сообщества микроорганизмов после прекращения антропогенного воздействия. Скорость разложения целлюлозы находится в прямой зависимости от содержания доступного микроорганизмам азота [Mendelssohn et al., 1999].

Слежение за изменением состава и структуры сообщества может проводиться как для таксономических, так и для трофических групп микроорганизмов. Следует отметить, что выбор исследуемой трофической группы (например, организмов, потребляющих легкодоступные органические вещества, крахмал, целлюлозу) должен соответствовать специфике исследуемого биоценоза и основным изменениям трансформации органики под влиянием антропогенных факторов.

Прежде чем вести речь о древних субстратах, обратимся к биоценологическим исследованиям целлюлазной активности степных и лесостепных почв. Скорость деструкции целлюлозы в почве может служить индикаторным показателем общей биологической активности в почвах, что, в свою очередь, будет отражать процессы самовосстановления почвенного сообщества микроорганизмов после прекращения кратковременного антропогенного воздействия. В нашей стране ведутся многолетние наблюдения за последовательными изменениями биологической активности почв с целью выработки стратегий природопользования в нарушенных местообитани- 
ях. Но даже в таких экологических работах целлюлазная активность исследуется нечасто. В экологических работах часто используются аппликационные методы, которые основаны на получении следов воздействия микроорганизмов или продуктов их жизнедеятельности на те или иные материалы непосредственно в почве. В середине XX в. было предложено учитывать скорость разложения клетчатки по убыли в весе полотна, заложенного в почву [Мишустин, Петрова, 1963; Мишустин, Востров, 1971; Методы..., 1980]. Синтез белков или аминокислот на ткани протекает интенсивно в той зоне, где она более активно разрушается микробами. Накопление на льняной или хлопчатобумажной ткани, помещенной в почву, заметного количества аминокислот, будет пропорционально биологической активности почвы. И, хотя при использовании этих методов определение биологической активности производится не непосредственно в почве, а в зоне контакта ее с льняным полотном, тем не менее эти методы дают возможность определять активности, приближающиеся к естественным. Лидером по доступности исполнения и информативности стала методика определения биологической активности почв, а именно целлюлозоразрушающей активности в слое 0-20 см путем закладки полотен на срок, близкий к длительности всего вегетационного сезона с поэтапным снятием данных. Данная методика рекомендуется для применения в заповедниках, в частности, подобные наблюдения в более полном объеме ведутся в одном из старейших заповедников России - Центрально-черноземном [Савченко и др., 1997], свыше 10 лет подобные стационарные наблюдения велись на территории лесничества Степное Ильменского государственного заповедника [Плеханова, Потапова (Прохорова), 2014, с. 1335-1338], pacположенного в степной зоне Челябинской области в пределах приподнятого Зауральского пенеплена. Лесничество, широко известное как заповедник «Аркаим», находится в одноименной долине. Для черноземов после распашки время самовосстановления целлюлазной активности как интегрального показателя биологической активности почв составляет, по нашей оценке, от 25 (полученные данные по равновесным целинным значениям) до 57 (прогноз самовосстановления) лет. Для изученных черноземов на глубине 0-40 см зависимость интенсивности целлюлозоразлагающей активности микроорганизмов от температуры воздуха является прямой тесной, $\mathrm{r}=0,82$ (корреляции Пирсона); зависимость от количества выпавших осадков является прямой средней, $\mathrm{r}=0,60$. Максимум биологической активности на всех изученных почвах приходится на слой 10-20 см, что обусловлено длительным сохранением влаги на этой глубине. Установлена четкая зависимость целлюлазной активности от поступающих тепла и влаги, выявлена динамика показателей внутри вегетационного сезона, выявлены лимитирующие факторы, в степной зоне - влага [Прохорова, Плеханова, 2016, с. 67-70; Plekhanova, 2018, p. 173]. Иными словами, в черноземных почвах внесенные антропогенные целлюлозные полотна разлагаются за один или несколько полевых сезонов в зависимости от влажности и глубины залегания. Соответственно, для исторических периодов и древности мы можем ожидать только отклика на вновь внесенный питательный субстрат оживанием именно тех покоящихся форм, что могут сохраняться.

В связи с вариабельностью свойств почв различных природных зон (и соответственно их целлюлозоразлагающей активности) для понимания скоростей процессов нами был проведен дополнительный термостатный эксперимент ${ }^{2}$ по установлению скоростей разложения целлюлозы почвами в природной зоне изучаемых кремированных погребений. Для эксперимента была взят усредненный почвогрунт заполнения круговой канавки вокруг погр. 5 (см. рис. 1). Эксперимент проведен в условиях постоянной температуры $30^{\circ} \mathrm{C}$ (термостат) и влажности 60 \% ПВ (поддержка каждые 5 суток). На всех сроках экспозиции в 5 повторностях достоверно для каждого срока была зафиксирована убыль в массе как для льняных дисков, так и для целлюлозных фильтров. Льняные диски демонстрируют убыль в массе от 5 до $10 \%$ на различных сроках экспозиции. Убыль в массе целлюлозных фильтров колеблется от 3 до $20 \%$, демонстрируя разброс данных. При этом нижний диск во всех случаях - как для льна, так и для целлюлозных фильтров - разлагался более интенсивно по сравнению с верхним диском, что 


\section{Льняные диски}

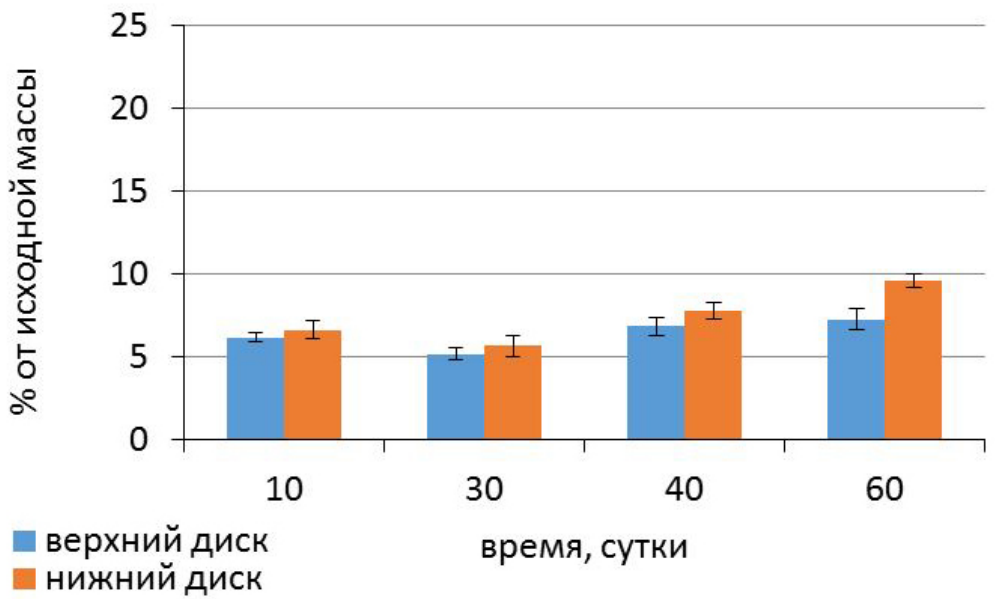

Целлюлозные фильтры

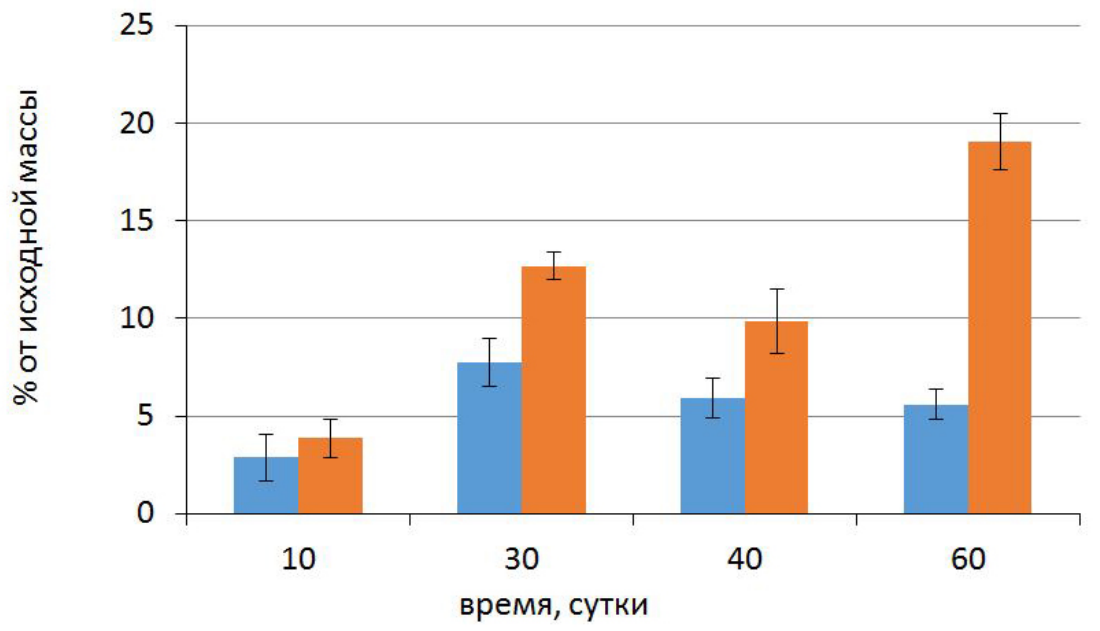

Рис. 1. Целлюлазная активность усредненных почвогрунтов круговой канавки погр. 5 (Кременье) в термостатном 60 -суточном эксперименте

Fig. 1. Cellulase activity of averaged soil of a circular groove of burial 5 (Kremenye) in a thermostatic 60-day experiment

объясняется концентрацией влажности на дне чашки Петри и плотным контактом с грунтом. Отметим, что эти данные сравнимы (с учетом уменьшения из-за легкого гранулометрического состава нашей почвы и более холодной природной зоны) с целлюлазной активностью как поселения Подкумского [Чернышева, 2013; Чернышева, 2015], так и данными для биогеоценозов [Прохорова, Плеханова, 2016], поскольку выражены в тех же единицах.

Для каждого срока экспозиции мы рассчитали скорость разложения целлюлозных субстратов, выраженную в \% убыли массы в сутки. При этом целлюлозные фильтры демонстрируют падение скорости разложения в зависимости со сроком экспозиции, но имеют флуктуации. Льняные диски демонстрируют повышенные скорости разложения субстрата в первые 10 суток эксперимента, на уровне $0,7 \%$ в сутки. К 30 -м суткам экспозиции скорость падает до $0,2 \%$ в сутки и держится на этом уровне до конца эксперимента, демонстрируя стабилизацию. Соответственно, выявлено, что начальные скоро- 
сти разложения льняных дисков в 3 раза выше, чем средняя стабильная скорость. Подобная картина начальных процессов почвообразования в биогеоценозах многократно демонстрировалась на различных свойствах [Плеханова, 2004; и др.]

Проводя сравнения целлюлазной активности культурных слоев для ключевого участка Подкумское-2 [Чернышева, 2015], отметим значимое ее повышение (в два раза по сравнению с фоном, в абсолютных значениях до $60 \%$ при фоновых значениях на уровне $17-$ $33 \%)$ всего в одном образце из двух десятков. Образец этот с глубины 10-30 см, в I зоне поселения (Б-338), где разрез культурного слоя расположен у стенки большой западины внутри загона, ограниченного со всех сторон развалами стен. Эта зона использовалась для содержания скота, где загоны выстилались подстилками.

Второе значимое повышение поселения Подкумское в абсолютных значениях невелико, на уровне $30 \%$, что сопоставимо с фоном, но находится на глубине 70-80 см II зоны эксплуатации (Разрез Б-341, Шурф 2), где не видны контуры развалов построек, что предполагает иной характер использования территории в аланское время (Жилая зона II-IV вв. н.э.), поэтому объяснимо антропогенным привносом вещества.

Эти данные хорошо сопоставимы с нашими, когда у нас в термостатном эксперименте за два месяца разлагается до 10-20\% внесенного субстрата серыми лесными супесями речной террасы Московской области, в то время как фоновые значения горных черноземов первой речной террасы КарачаевоЧеркесской Республики демонстрируют максимальные значения до 30-40 \%. Антропогенная нагрузка от проживания населения оставляет след в виде измененной ферментативной активности почв.

Переходя от целлюлазной активности естественных почв биогеоценозов, через подтвержденные следы различного антропогенного воздействия, в частности, загонного содержания скота, к кремированным захоронениям, остановимся на фоновых значениях почвы курганной насыпи 800-летнего возраста. Здесь отмечено достоверное увеличение КОЕ в верхнем горизонте фоновой почвы до 97 \% (см. табл. 1), что свидетельствует о работоспособности примененного метода.

Также увеличение КОЕ целлюлозолитиков по сравнению с почвенным агаром без карбоксиметилцеллюлозы получено еще в трех образцах из массива 22 образцов. Слабое превышение - на 17 \% - было зафиксировано в центре погр. 8, в его придонной части. В канавке погр. 5, в восточной ее части, также было отмечено увеличение КОЕ целлюлозолитиков на $14 \%$.

Превышение на $30 \%$ зафиксировано в коричневом грунте обрамления, в кремации ямы 47 могильника Щурово. Поскольку температура горения при кремировании превышает $750{ }^{\circ} \mathrm{C}$, неполное сгорание горящих материалов, входящих в состав самих кремированных останков, возможно исключить. В связи с этим мы предполагаем либо укутывание этой кремации в ткани, либо размещение их на деревянной конструкции (метод не позволяет отделить лигнин), которая сгнила, и кости кремации просели вниз, где в данный момент грунты демонстрируют превышение численности микроорганизмов на почвенном агаpe, содержащем карбоксиметилцеллюлозу.

\section{Заключение}

Целлюлазная активность почвогрунтов погребальных сооружений и захоронений в зоне серых лесных супесчаных почв зафиксирована на уровне до 20 \% на примере образцов из окружной канавки погр. 5 в ходе лабораторного 60-суточного термостатного эксперимента при $22{ }^{\circ} \mathrm{C}$.

Впервые методом чашечного посева в шести повторностях, по разнице в числе колониеобразующих единиц на среде с внесением целлюлозного субстрата, зафиксированы превышения целлюлазной активности в трех образцах почвогрунтов кремированных захоронений 800-летнего возраста. Отметим, что при детальном изучении культурных слоев поселения Подкумское, значимая разница по целлюлазной активности получена всего в двух образцах [Чернышева, 2015], но хорошо и логично объяснима типом хозяйственного использования территории.

Фоновые значения целлюлазной активности в верхнем горизонте значительно 
Cellulosolitic Microorganisms Activity as an Indicator of Details Funeral Ceremony

\section{Таблица 1. Целлюлозолитическая активность почв и грунтов кремированных захоро- нений и прилегающих погребальных конструкций}

\section{Table 1. Cellulozolytic activity of soils of cremated burials}

\begin{tabular}{|c|c|c|c|}
\hline \multirow{2}{*}{$\begin{array}{c}\text { Характеристика анализируемого грунта, } \\
\text { средняя глубина, } \\
\text { см: [положение по тахеометру] }\end{array}$} & \multicolumn{2}{|c|}{$\begin{array}{l}\text { Численность микробных колоний, } \\
\text { млн КОЕ / г почвы }\end{array}$} & \multirow{2}{*}{$\begin{array}{c}\text { Увеличение чис- } \\
\text { ленности колоний } \\
\text { при добавлении } \\
\text { целлюлозы в поч- } \\
\text { венный агар, \% }\end{array}$} \\
\hline & Почвенный агар & $\begin{array}{c}\text { Почвенный агар } \\
\text { с добавлением } \\
\text { целлюлозы (КМЦ) }\end{array}$ & \\
\hline \multicolumn{4}{|c|}{ Могильник Кременье } \\
\hline \multicolumn{4}{|c|}{ Разрез современной почвы на насыпи кургана } \\
\hline A1 $(10 \mathrm{~cm})$ & $0.97 \pm 0.03$ & $1.91 \pm 0.57$ & 97 \\
\hline AB насыпи (20 см) & $0.63 \pm 0.03$ & $0.62 \pm 0.10$ & нет \\
\hline AB насып и (38 cм) & $0.59 \pm 0.01$ & $0.83 \pm 0.11$ & 41 \\
\hline $\begin{array}{c}\text { Фрагмент строительной конструкции } \\
\text { кургана с печиной }(60 \text { см) }\end{array}$ & $0.88 \pm 0.18$ & $0.87 \pm 0.05$ & нет \\
\hline В насыпи $(75 \mathrm{~cm})$ & $0.85 \pm 0.01$ & $0.65 \pm 0.01$ & нет \\
\hline \multicolumn{4}{|c|}{$\begin{array}{c}\text { Могильник Кременье } \\
\text { Захоронения с кремированными останками }\end{array}$} \\
\hline \multicolumn{4}{|c|}{ Раскоп 1, участок 8, погребение 5, заполнение канавки } \\
\hline Северная часть, придонный слой & $1.66 \pm 0.26$ & $1.31 \pm 0.03$ & нет \\
\hline Восточная часть, низ кремации & $0.97 \pm 0.01$ & $1.11 \pm 0.09$ & 14 \\
\hline $\begin{array}{l}\text { Левая сторона восточной части } \\
\text { Коричневый грунт [тах. 2393] }\end{array}$ & $0.68 \pm 0.08$ & $0.71 \pm 0.05$ & нет \\
\hline $\begin{array}{c}\text { Правая сторона восточной части } \\
\text { [тахеометр 2394] }\end{array}$ & $2.03 \pm 0.07$ & $1.95 \pm 0.69$ & нет \\
\hline $\begin{array}{c}\text { Нижний слой восточной части } \\
\text { Черный грунт [тах. 2395] }\end{array}$ & $1.26 \pm 0.16$ & $1.22 \pm 0.22$ & нет \\
\hline $\begin{array}{c}\text { Восточная часть } \\
\text { Коричнево-охристый грунт [тах. 2396] }\end{array}$ & $1.44 \pm 0.24$ & $1.54 \pm 0.08$ & нет \\
\hline Западная часть [тах. 2434] & $1.50 \pm 0.12$ & $1.31 \pm 0.05$ & нет \\
\hline $\begin{array}{c}\text { Заполнение канавки } \\
\text { Усредненный образец грунта }\end{array}$ & $3.04 \pm 0.04$ & $3.07 \pm 0.09$ & нет \\
\hline \multicolumn{4}{|c|}{ Раскоп 1, участок 10, погребение 9} \\
\hline $\begin{array}{c}\text { Погребение } 9 \\
\text { Грунт под костяком }\end{array}$ & $3.42 \pm 0.08$ & $3.11 \pm 0.11$ & нет \\
\hline $\begin{array}{c}\text { Погребение } 10 \\
\text { Контакт погребения и материка }\end{array}$ & $1.97 \pm 0.15$ & $1.76 \pm 0.16$ & нет \\
\hline \multicolumn{4}{|c|}{ Раскоп 1, участок 9, погребение 8} \\
\hline $\begin{array}{c}\text { Центр погребения } \\
\text { Дно центральной части } \\
\end{array}$ & $2.53 \pm 0.07$ & $2.30 \pm 0.11$ & нет \\
\hline $\begin{array}{c}\text { Центр погребения } \\
\text { придонная часть }\end{array}$ & $1.06 \pm 0.08$ & $1.24 \pm 0.05$ & 17 \\
\hline Правая сторона придонной части & $1.33 \pm 0.03$ & $1.38 \pm 0.02$ & нет \\
\hline Левая стенка & $0.71 \pm 0.10$ & $0.69 \pm 0.12$ & нет \\
\hline \multicolumn{4}{|c|}{ Могильник «Щурово», кремированные захоронения } \\
\hline $\begin{array}{c}\text { Раскоп II, участок } 15, \text { яма 47, обрамл е- } \\
\text { ние кремации, коричневый грунт }\end{array}$ & $0.57 \pm 0.01$ & $0.73 \pm 0.01$ & 29 \\
\hline $\begin{array}{c}\text { Раскоп II, участок } 15, \text { яма 47, } \\
\text { «тело» кремации }\end{array}$ & $0.57 \pm 0.08$ & $0.54 \pm 0.02$ & нет \\
\hline $\begin{array}{c}\text { Раскоп II, участок 18, кв. 577, } \\
\text { круговая канавка }\end{array}$ & $0.13 \pm 0.02$ & $0.15 \pm 0.01$ & нет \\
\hline
\end{tabular}

превышают активность почвогрунтов, но в горизонте на глубине до 40 см уже сопоставимы с максимумами в кремированных грунтах.
Кремированные объекты позволяют предполагать выгорание привнесенных в древности целлюлозосодержащих предметов, но даже в этом случае придонная часть 
погр. 8 демонстрирует некоторое повышенное значение, что позволяет предполагать тканевую подстилку при захоронении кремированных остатков. Этот же образец продемонстрировал повышенную кератинолитическую активность [Каширская и др., 2018б].

В кремации, расположенной в яме 47 Щуровского могильника, где превышение численности КОЕ целлюлозолитических микроорганизмов составляло $30 \%$, предполагается исходное присутствие целлюлозы в древности.

По сравнению с кератинолитической активностью, где ранее нами демонстрировалось превышение до 8 раз по сравнению с фоном, целлюлазная активность намного более сложна в интерпретации относительно фоновых значений ввиду высокой распространенности этого биополимера в природе и круговоротах в биогеоценозах. При этом, если превышение зафиксировано, то оно не является случайностью, позволяя получать логичные объяснения археологическим контекстом.

\section{ПРИМЕЧАНИЯ}

1 Работа выполнена в рамках госзадания № AААА-А18-118013190175-5 «Развитие почв в условиях меняющегося климата и антропогенных воздействий», в системе «Парус» - 0191-2019-0046, аналитическая часть при поддержке гранта РФФИ № 17-29-04257 офи-м «Археологическая микробиология: теория и практика выявления исходного присутствия органических материалов в археологических исследованиях», рук. А.В. Борисов.

This work was supported as part of state assignment no. AAAA-A18-118013190175-5 "Soil development in a changing climate and anthropogenic impacts", in the "Parus" system - 0191-2019-0046, analytical part supported by the RFBR grant no. 17-2904257 ofi -m “Archaeological Microbiology: Theory and Practice of Identifying the Initial Presence of Organic Materials in Archaeological Research", Borisov A.V.

2 Авторы выражают благодарности к.б.н., с.н.с. Т.Э. Хомутовой за консультативную методическую помощь, а также магистранту Пущинского государственного естественнонаучного института А.А. Петросян за участие в поддержке термостатного эксперимента по установлению скоростей разложения целлюлозы почвогрунтами.

\section{СПИСОК ЛИТЕРАТУРЫ}

Борисов А. В., Бухонов А. В., Гак Е. И., Плеханова Л. Н., 2013. Инфраструктура катакомбного поселения Рыкань-3 в свете междисциплинарных исследований // Археология Восточно-Европейской степи : материалы IV Нижневолж. Междунар. археол. конф. Саратов : Изд-во СГУ. С. 66-74.

Демкин В. А., Демкина Т. С., Удальцов С. Н., 2014. Реконструкция погребальной пищи в глиняных сосудах из курганных захоронений с использованием фосфатного и микробиологического методов // Вестник археологии, антропологии и этнографии. № 2 (25). С. 148-159.

Дмитриев Е. А., 1995. Математическая статистика в почвоведении. М. : Изд-во МГУ. 320 с.

Каширская Н. Н., Плеханова Л. Н., Удальцов С. Н., Чернышева Е. В., Борисов А. В., 2017а. Механизмы и временной фактор ферментативной организации палеопочв // Биофизика. Т. 62, № 6. С. 1022-1029. DOI: https://doi.org/10.1134/S0006350917060094.

Каширская Н. Н., Чернышева Е. В., Плеханова Л. Н., Борисов А. В., 2017б. «Биологический» и минеральный фосфор в культурном слое // Палеопочвы, палеоэкология, палеоэкономика. Пущино : КИАС. С. 94-98.

Каширская Н. Н., Петросян А. А., Плеханова Л. Н., Сыроватко А. С., Мякшина Т. Н., Потапова А. В., 2018 a. Кремированные средневековые захоронения и попытки идентификации присутствия шерстяных субстратов // Археология евразийских степей. № 4. С. 166-171.

Каширская Н. Н., Плеханова Л. Н., Петросян А. А., Потапова А. В., Сыроватко А. С., Клещенко А. А., Борисов А. В., 2018б. Подходы к выявлению шерсти по численности кератинолитических микроорганизмов в грунтах древних и средневековых погребений // Нижневолжский археологический вестник. Т. 17, № 2. C. 95-107. DOI: https://doi.org/10.15688/nav.jvolsu.2018.2.8.

Каширская Н. Н., Плеханова Л. Н., Чернышева Е. В., Ельцов М. В., Удальцов С. Н., Борисов А. В., 2020. Пространственно-временные особенности фосфатазной активности естественных и антропогенно-преобразованных почв // Почвоведение. № 1. С. 89-101. DOI: https://doi.org/10.31857/S0032180X20010098.

Методы почвенной микробиологии и биохимии, 1980. М. : Изд-во МГУ. 224 с. 
Методы почвенной микробиологии и биохимии, 1991. М. : Изд-во МГУ. 304 с.

Мишустин Е. Н., Петрова А. Н., 1963. Определение биологической активности почвы // Микробиология. Т. 32. Вып. 3. С. 479-483.

Мишустин Е. Н., Востров И. С., 1971. Аппликационные методы в почвенной микробиологии // Микробиологические и биохимические исследования почв. Киев : Урожай. С. 3-12.

Плеханова Л. Н., 2004. Природно-антропогенная эволюция почв речных долин степного Зауралья во второй половине голоцена : автореф. дис. ... канд. биол. наук. М. 24 с.

Плеханова Л. Н., 2017. Проблемы поиска эталонных почв степного Зауралья для создания красной книги почв // Аридные экосистемы. № 7. С. 171-177.

Плеханова Л. Н., 2019. Антропогенная деградация почв речных террас Волго-Уральского региона в эпоху бронзы и ее влияние на современный почвенно-растительный покров // Аридные экосистемы. Т. 25, № 3 (80).C. $53-59$.

Плеханова Л. Н., Потапова (Прохорова) А. В., 2014. Мониторинг целлюлазной активности почв как биологического индикатора восстановления залежей степного Зауралья после введения заповедного режима // Вестник Тамбовского университета. Серия: Естественные и технические науки. Т. 19, № 5. C. $1335-1339$.

Почвенный и биотический мониторинг заповедных экосистем, 1996. М. : КМК Scientific Press LTD. 105 c.

Прохорова А. В., Плеханова Л. Н., 2016. Прогнозная оценка скорости восстановления залежных черноземов степного Зауралья при введении заповедного режима // Проблемы региональной экологии. № 2. С. 67-71.

Савченко Л. А., Бойко О. С., Оликова И. С., 1997. Целлюлозоразрушающая активность мощного типичного чернозема в зависимости от режима его использования и экологических факторов // Многолетняя динамика природных процессов и биологическое разнообразие заповедных экосистем Центрального Черноземья и Алтая. Труды Центрально-черноземного госзаповедника. Вып. 15. М. : КМК Scientific Press Дев. С. 30-44.

Сыроватко А. С., 2014. Могильники с кремациями на Средней Оке второй половины I тыс. н.э. // Российская археология. № 4. С. 48-61.

Сыроватко А. С., Фомченко Э. Э., 2015. Курганная группа в Кременье - новый археологический сюжет // Оки связующая нить: археология Среднего Поочья : материалы VII-VIII регион. науч.-практ. конф. Ступино : Ступинский историко-художественный музей. С. 132-138.

Чернышева Е. В., 2015. Влияние древнего антропогенного воздействия на биологическую активность почв Кисловодской котловины : автореф. дис. ... канд. биол. наук. Воронеж. 24 с.

Чернышева Е. В., Каширская Н. Н., Борисов А. В., Журавлев А. Н., Демкин В. А., 2013. Биомасса и активность микроорганизмов в современных погребенных каштановых почвах Нижнего Поволжья // Вестник Тамбовского университета. Серия: Естественные и технические науки. Т. 18, № 3. С. 842-846.

Kashirskaya N., Chernysheva E., Plekhanova L., Borisov A., 2019. Thermophilic Microorganisms as an Indicator of Soil Microbiological Contamination in Antiquity and at the Present Time // International Multidisciplinary Scientific Geo Conference SGEM. T. 19, № 3.2. P. 569-574. DOI: https://doi.org/10.5593/sgem2019/3.2/S13.074.

Mendelssohn I. A., Sorrell B. K., Brix H., Schierup H.-H., Lorenzen B., Maltby E., 1999. Controls on Soil Cellulose Decomposition Along a Salinity Gradient in a Phragmites Australis Wetland in Denmark // Aquatic Botany. Vol. 64, № 3-4. P. 381-398.

Plekhanova L. N., 2018. Cellulase Activity in Anthropogenically Disturbed Chernozems // International Multidisciplinary Scientific GeoConference SGEM. Vol. 18, № 5.2. P. 173-180.

\section{REFERENCES}

Borisov A.V., Bukhonov A.V., Gak E.I., Plekhanova L.N., 2013. Infrastruktura katakombnogo poseleniya Rykan'-3 v svete mezhdistsiplinarnykh issledovaniy [Infrastructure of the Catacomb Settlement Rykan-3 in the Light of Interdisciplinary Research]. Arkheologiya Vostochno-Yevropeyskoy stepi: materialy IV Nizhnevolzh. Mezhdunar. arkheol. konf. [Archeology of the East European Steppe. Materials of $\mathrm{IV}^{\text {th }}$ International Archaeological Conference of Low Volga Region]. Saratov, SSU, pp. 66-74.

Demkin V.A., Demkina T.S., Udaltsov S.N., 2014. Rekonstruktsiya pogrebal'noy pishchi v glinyanyh sosudah iz kurgannyh zahoroneniy s ispol'zovaniem fosfatnogo i mikrobiologicheskogo metodov [Reconstruction of 
Burial Food in Clay Vessels from Mound Burial Sites Using Phosphate and Microbiological Methods]. Vestnik arheologii, antropologii I etnografii [Bulletin of Archaeology, Anthropology and Ethnography], no. 2 (25), pp. 148-159.

Dmitriev E.A., 1995. Matematicheskaya statistika v pochvovedenii [Mathematical Statistics in Soil Science]. Moscow, MSU. 320 p.

Kashirskaya N.N., Plekhanova L.N., Udaltsov S.N., Chernysheva E.V., Borisov A.V., 2017a. Mekhanizmyi vremennoy faktor fermentativnoy organizatsii paleopochv [The Mechanisms and Time Factor of the Enzyme Structure of a Paleosoil]. Biofizika [Biophysics], vol. 62, no. 6, pp. 1022-1029. DOI: https://doi.org/10.1134/ S0006350917060094.

Kashirskaya N.N., Chernysheva E.V., Plekhanova L.N., Borisov A.V., 2017б. "Biologicheskiy" i mineral'nyy fosfor v kul'turnom sloye ["Biological" and Mineral Phosphorus in the Cultural Layer]. Paleopochvy, paleoekologiya, paleoekonomika [Paleosols, paleoecology, paleo-economics]. Puschino, KIAS, pp. 94-98.

Kashirskaya N.N., Petrosyan A.A., Plekhanova L.N., Syrovatko A.S., Myakshina T.N., Potapova A.V., 2018 a. Kremirovannyye srednevekovyye zakhoroneniya i popytki identifikatsii prisutstviya sherstyanykh substratov [Cremated Medieval Burials and Attempts to Identify Traces of Woolen Substrates]. Arkheologiya Evraziyskikh stepey [Archaeology of the Eurasian Steppes], no. 4, pp. 166-171.

Kashirskaya N.N., Plekhanova L.N., Petrosyan A.A., Potapova A.V., Syrovatko A.S., Kleschenko A.A., Borisov A.V., 2018б. Podhody k vyyavleniyu shersti po chislennosti keratinoliticheskih mikroorganizmov v gruntah drevnih i srednevekovyh pogrebeniy [The Identification of Wool by the Number of Keratinolytic Microorganisms in the Ground of Ancient and Medieval Burials]. Nizhnevolzhskiy arkheologicheskiy vestnik [The Lower Volga Archaeological Bulletin], vol. 17, no. 2, pp. 95-107. DOI: https://doi.org/10.15688/nav.jvolsu.2018.2.8.

Kashirskaya N.N., Plekhanova L.N., Chernisheva E.V., Eltsov M.V., Udaltsov S.N., and Borisov A.V., 2020. Prostranstvennovremennye osobennosti fosfataznoy aktivnosti estestvennyh $i$ antropogenno-preobrazovannyh pochv [Temporal and Spatial Features of Phosphatase Activity in Natural and Human-Transformed Soils]. Pochvovedenie [Soil Science], no. 1,pp. 89-101. DOI: https://doi.org/10.31857/S0032180X20010098.

Metody pochvennoy mikrobiologii i biohimii [Methods of Soil Microbiology and Biochemistry], 1980. Moscow, MSU. $224 \mathrm{p}$.

Metody pochvennoy mikrobiologii i biohimii [Methods of Soil Microbiology and Biochemistry], 1991. Moscow, MSU. 304 p.

Mishustin E.N., Petrova A.N., 1963. Opredeleniye biologicheskoy aktivnosti pochvy [Determination of the Biological Activity of the Soil]. Microbiologiya [Microbiology], vol. 32, iss. 3, pp. 479-483.

Mishustin E.N., Vostrov I.S., 1971. Applikatsionnyye metody v pochvennoy mikrobiologii [Application Methods in Soil Microbiology]. Mikrobiologicheskiye i biokhimicheskiye issledovaniya pochv [Microbiological and Biochemical Studies of Soils]. Kiev, Urozhay Publ., pp. 3-12.

Plekhanova L.N., 2004. Prirodno-antropogennaya evolyutsiya pochv rechnykh dolin stepnogo Zaural'ya vo vtoroy polovine golotsena: avtoref. dis. ... kand. ist. nauk [Natural-Anthropogenic Evolution of the Soils of River Valleys of the Steppe Trans-Urals in the Second Half of the Holocene. Cand. biol. sci. abs. diss.]. Moscow. 24 p.

Plekhanova L.N., 2017. Problemy poiska etalonnyh pochv stepnogo Zaural'ya dlya sozdaniya krasnoy knigi pochv [Searching for Benchmark Soils in the Steppe Zone of the Trans-Ural Plateau to Compile the Red Book of Soils]. Aridnye ekosistemy [Arid Ecosystems], vol. 7, no. 3, pp. 171-177. DOI: https://doi.org/10.1134/ S2079096117030076.

Plekhanova L.N., 2019. Anthropogenic Degradation of Soils on River Terraces in the Volga-Ural Region in the Bronze Age and Its Effect on the Modern Soil-Plant Cover. Aridnye ekosistemy [Arid Ecosystems], 2019, vol. 25, iss. 3 (80), pp. 53-59. DOI: https://doi.org/10.1134/S2079096119030077.

Plekhanova L.N., Potapova (Prokhorova) A.V., 2014. Monitoring tsellyulaznoy aktivnosti pochv kak biologicheskogo indikatora vosstanovleniya zalezhey stepnogo Zaural'ya posle vvedeniya zapovednogo rezhima [Monitoring of Cellulase Activity of Soils as a Biological Indicator of the Restoration of Steppe Zauralye Deposits After the Introduction of the Reserve Regime]. Vestnik Tambovskogo universiteta. Seriya: Yestestvennyye itekhnicheskiye nauki [Tambov University Reports. Series: Natural and Technical Sciences], vol. 19, no. 5, pp. 1335-1339.

Pochvennyy i bioticheskiy monitoring zapovednykh ekosistem [Soil and Biotic Monitoring of Protected Ecosystems], 1996. Moscow, KMK Scientific Press LTD. 105 p. 
Prokhorova A.V., Plekhanova L.N., 2016. Prognoznaya otsenka skorosti vosstanovleniya zalezhnykh chernozemov stepnogo Zaural'ya pri vvedenii zapovednogo rezhima [Predictive Estimation of the Rate of Restoration of Fallow Chernozems of the Steppe Trans-Urals with the Introduction of the Reserve Regime]. Problemy regional'noy ekologii [Problems of Regional Ecology], no. 2, pp. 67-71.

Savchenko L.A., Boyko O.S., Olikova I.S., 1997. Tsellyulozorazrushayushchaya aktivnost' moshchnogo tipichnogo chernozema v zavisimosti ot rezhima yego ispol'zovaniya i ekologicheskikh faktorov [Cellulose-Destructive Activity of a Powerful Typical Chernozem Depending on the Mode of its Use and Environmental Factors]. Mnogoletnyaya dinamika prirodnykh protsessov i biologicheskoye raznoobraziye zapovednykh ekosistem Tsentral'nogo Chernozem'ya i Altaya. Trudy Tsentral'no-chernozemnogo goszapovednika [Long-term Dynamics of Natural Processes and Biological Diversity of Protected Ecosystems of the Central Black Earth Region and Altai. Proceedings of the Central Black Earth State Reserve], vol. 15. Moscow, KMK Scientific Press, pp. 30-44.

Syrovatko A.S., 2014. Mogil'niki s krematsiyami na Sredney Oke vtoroy poloviny I tys. n.e. [Burials with Cinerations on the Middle Oka River of the Second half of the I millenium AD]. Rossiyskaya arkheologia [Russian Archaeology], no. 4, pp. 48-61.

Syrovatko A.S., Fomchenko E.E., 2015. Kurgannaya gruppa v Kremen'e-novyy arheologicheskiy syuzhet [Kurgan group in the Kremenieu - a new archaeological story]. Oki svyazuyushchaya nit': arheologiya Srednego Pooch'ya: materialy VII-VIII region. nauch.-prakt. konf. [Oka is Linking Thread: Archaeology of the Middle Oka Region: Proceedings of VII-VIII Regional Scientific-Practical Conference. Stupino, Stupino History and Art Museum, pp. 132-138.

Chernysheva E.V., 2015. Vliyaniye drevnego antropogennogo vozdeystviya na biologicheskuyu aktivnost'pochv Kislovodskoy kotloviny: avtoref. ... kand. biol. nauk [The Influence of the Ancient Anthropogenic Impact on the Biological Activity of Soils of the Kislovodsk Depression. Cand. biol. sci. abs. diss.]. Voronezh. 24 p.

Chernysheva E.V., Kashirskaya N.N., Borisov A.V., Zhuravlev A.N., Demkin V.A., 2013. Biomassa i aktivnost' mikroorganizmov v sovremennykh pogrebennykh kashtanovykh pochvakh Nizhnego Povolzh'ya [Biomass and Activity of Microorganisms in Modern Buried Chestnut Soils of the Lower Volga]. Vestnik Tambovskogo universiteta. Seriya: Yestestvennyye i tekhnicheskiye nauki [Tambov University Reports. Series: Natural and Technical Sciences], vol. 18, no. 3, pp. 842-846.

Kashirskaya N., Chernysheva E., Plekhanova L., Borisov A., 2019. Thermophilic Microorganisms as an Indicator of Soil Microbiological Contamination in Antiquity and at the Present Time. International Multidisciplinary Scientific Geo Conference SGEM, vol. 19, no. 3.2, pp. 569-574. DOI: https://doi.org/10.5593/sgem2019/3.2/ S13.074.

Mendelssohn I.A., Sorrell B.K., Brix H., Schierup H.-H., Lorenzen B., Maltby E., 1999. Controls on Soil Cellulose Decomposition Along a Salinity Gradient in a Phragmites Australis Wetland in Denmark. Aquatic Botany, vol. 64 , no. 3-4, pp. 381-398.

Plekhanova L.N., 2018. Cellulase Activity in Anthropogenically Disturbed Chernozems. International Multidisciplinary Scientific GeoConference SGEM, vol. 18, no. 5.2, pp. 173-180.

\section{Information About the Authors}

Liudmila N. Plekhanova, Candidate of Sciences (Biology), Associate Professor, Senior Researcher at the Archaeological Soil Science Laboratory, Institute of Physico-Chemical and Biological Problems of Soil Science of the Russian Academy of Sciences, Institutskaya St., 2, 142290 Pushchino, Russian Federation, dianthus1@rambler.ru, https://orcid.org/0000-0002-3611-7783

Natalya N. Kashirskaya, Candidate of Sciences (Biology), Senior Researcher of the Archaeological Laboratory of Soil Science, Institute of Physico-Chemical and Biological Problems of Soil Science of the Russian Academy of Sciences, Institutskaya St., 2, 142290 Pushchino, Russian Federation, nkashirskaya81@gmail.com,https://orcid.org/0000-0001-8353-3192

Alexander S. Syrovatko, Candidate of Sciences (History), Head, Kolomna Archeological Research Center, Kremlevskaya St., 5, 140400 Kolomna, Russian Federation, sasha.syr@rambler.ru,https://orcid.org/0000-0002-6847-4160 


\section{Информация об авторах}

Людмила Николаевна Плеханова, кандидат биологических наук, доцент, старший научный сотрудник лаборатории археологического почвоведения, Институт физико-химических и биологических проблем почвоведения РАН, ул. Институтская, 2, 142290 г. Пущино, Российская Федерация, dianthus1@rambler.ru, https://orcid.org/0000-0002-3611-7783

Наталья Николаевна Каширская, кандидат биологических наук, старший научный сотрудник лаборатории археологического почвоведения, Институт физико-химических и биологических проблем почвоведения РАН, ул. Институтская, 2, 142290 г. Пущино, Российская Федерация, nkashirskaya81@gmail.com, https://orcid.org/0000-0001-8353-3192

Александр Сергеевич Сыроватко, кандидат исторических наук, директор, Коломенский археологический научный центр, ул. Кремлевская, 5, 140400 г. Коломна, Российская Федерация, sasha.syr@rambler.ru, https://orcid.org/0000-0002-6847-4160 